\title{
S10 - Herramientas moleculares aplicadas al estudio de aguas para el consumo humano, comunidad El Cacao, Nicaragua
}

\author{
Leandro A. Paramo*, Tania S. Garmendia, Jennifer Villalta \\ Programa de Investigacion Estudios Nacionales y Servicios Ambientales, Universidad Nacional de Ingeniería, Nicaragua \\ *Autor al que se dirige la correspondencia: lparamo2014@gmail.com
}

\section{Resumen}

C e determinó la presencia de contaminantes microbianos en aguas de consumo humano de la comunidad El Cacao, Mosonte, Nueva Segovia. El análisis se realizó tanto por métodos microbiológicos como por vía molecular analizando su interrelación con las enfermedades que se observan en la comunidad. Se obtuvo la presencia de coliformes fecales, totales y Escherichia coli desde la captación hasta el tanque de almacenamiento. Los aislados identificados pertenecen a las bacterias del tipo Alcaligenes y Paenalcaligenes, además de Stenotrophomonas y Serratia. Las cuales son bacterias acuáticas y están asociadas a diversas enfermedades. Además se identificó la presencia de Aspergillus que han sido bien reportados en diversas enfermedades humanas.

Palabras claves: Alcaligenes, Serratia, Aspergillus, microbiología de aguas, enfermedades transmitidas por agua

\begin{abstract}
$\mathrm{T}$

he presences of microbial contaminants in water for human consumption from El Cacao community, Mosonte, Nueva Segovia was determined. Analysis was carried out by microbiological and molecular methods, analyzing their interaction with the diseases seen in the community. Fecal coliforms and Escherichia coli total were obtained from the catchment to the storage tank. Isolates identified bacteria belonging to Paenalcaligenes, Alcaligenes, Stenotrophomonas and Serratia genus, These are aquatic bacteria and are associated with various diseases. Furthermore, Aspergillus was identified and has been well reported in various human diseases.
\end{abstract}

Keywords: Alcaligenes, Serratia, Aspergillus, Water microbiology, Water-.borne diseases 